\title{
Effect of Flavopiridol on Cell Cycle, Apoptosis and Biomolecule Structure Changes in Breast Cancer Stem Cells
}

\section{Meme Kanseri Kök Hücrelerinde Flavopiridolün Hücre Döngüsü, Apoptozis ve Biyomolekül Yapı Değişimleri Üzerine Etkisi}

(D) Eda AÇIKGÖZ11, iD Günnur GÜLER², iD Gülperi ÖKTEM³

IVan Yüzüncü Yıl University Faculty of Medicine, Department of Medical Histology and Embryology, Van, Turkey

2̇̇zmir Ekonomi University Faculty of Engineering, Department of Biomedical Engineering, İzmir, Turkey

${ }^{3}$ Ege University Faculty of Medicine, Department of Medical Histology and Embryology, İzmir, Turkey

\section{ABSTRACT}

Objective: Cancer stem cells (CSCs) are a small population in cancer, which are responsible for therapeutic resistance, relapse and metastasis. Flavopiridol has antitumor activity against various types of cancer cells. The mechanism of action of flavopiridol on CD44+/ CD24- breast CSCs has not yet been fully elucidated. The aim of this study was to evaluate the mechanism of action of flavopiridol on breast CSCs (BCSC) in terms of apoptosis, cell cycle and biomolecular changes.

Methods: In human breast cancer, cells with CD44+/CD24markers were isolated from MCF-7 cell line using flow cytometry. The induction of apoptosis was investigated by Annexin-V. The effect of flavopiridol on cell cycle arrest was determined and the percent of cell populations at G0/G1, S and G2/M cycles were identified. The effect of the drug on three-dimensional cell cultures was investigated using a multicellular tumor spheroid model. In addition, the effect of flavopiridol on biomolecules has been evaluated using Fourier transform infrared (FTIR) spectroscopy, which has recently been used effectively in various scientific fields.

Results: Flavopiridol especially induced early apoptosis. Cell cycle analyses revealed that flavopiridol induced cell cycle arrest in G0/G1 phase. Decreased number and diameter of spheroids was observed following flavopiridol treatment. ATR-FTIR data showed that treatment with flavopiridol led to significant changes in nucleic acids.
ÖZ

Amaç: Kanser kök hücreleri $(\mathrm{KKH})$ terapötik direnç, relaps ve metastazdan sorumlu olan oldukça küçük bir hücre popülasyondan oluşmaktadır. Flavopiridol (Alvocidib), çeşitli KKH'lerine karşı anti-tümör aktiviteye sahiptir. Flavopiridolün CD44+/CD24meme KKH (MKKH) üzerindeki etki mekanizması henüz tam olarak aydınlatılamamıştır. Bu çalışmada, apoptozis, hücre döngüsü ve biyomoleküler değişiklikler dahil olmak üzere flavopiridolün MKKH üzerindeki etki mekanizmasının çeşitli şekillerde değerlendirilmesi amaçlanmıştır.

Yöntemler: MCF-7 KKH hattı içerisindeki CD44+/CD24- yüzey belirteç özelliklerine sahip $\mathrm{MKKH}$, akış sitometrisi kullanılarak izole edilmiştir. Apoptozis indüksiyonu Annexin-V yöntemi ile incelenmiştir. Flavopiridolün hücre döngüsü tutulumu üzerine etkisi Muse Cell Analyzer ile belirlenmiş ve G0/G1, S ve G2/M döngüsündeki hücre populasyonları yüzde olarak ifade edilmiştir. İlacın üç boyutlu hücre kültürlerindeki etkisi multiselüler tümör sferoid modeli kullanılarak incelenmiştir. Buna ek olarak, flavopiridolün biyomoleküller üzerindeki etkisi, son zamanlarda çeşitli alanlarda oldukça etkin bir şekilde kullanılan Fourier dönüşüm kızılötesi (FTIR) spektroskopisi kullanılarak değerlendirilmiştir.

Bulgular: Flavopiridol spesifik olarak erken apoptozu indüklemiştir. Hücre döngü analizleri, flavopiridolün G0/G1 arrestine yol açtığını ortaya koymuştur. Flavopiridol uygulamasından sonra sferoid sayısı ve çapında azalma tespit edilmiştir. ATR-FTIR verileri, flavopiridol
Address for Correspondence: Eda Açıkgöz, Van Yüzüncü Yıl University Faculty of Medicine, Department of Medical Histology and Embryology, Van, Turkey

E-mail: acikgozedaa@gmail.com ORCID ID: orcid.org/0000-0002-6772-3081
Received: 10.07.2019

Accepted: 15.10 .2019

Cite this article as: Açıkgöz E, Güler G, Gülperi Ö. Effect of Flavopiridol on Cell Cycle, Apoptosis and Biomolecule Structure Changes in Breast Cancer Stem Cells. Bezmialem Science 2020;8(3):275-81. 
Conclusion: According to the data obtained in this study, flavopiridol exhibits anticancer effects by altering the structure/ expression level of nucleic acids and changing cell cycle progression and inducing apoptosis. These finding reveals that flavopiridol can be an effective antitumor agent for the treatment of breast cancer after in vivo and phase studies are completed.

Keywords: Flavopiridol, breast cancer, cancer stem cell, apoptosis, cell cycle, FTIR spectroscopy uygulamasının hücre içindeki nükleik asitlerde önemli değişimlere yol açtı̆̆ını göstermiştir.

Sonuç: Elde edilen bulgular, flavopiridolün nükleik asitlerin yapısını/expresyon seviyesini ve hücre döngüsünü değiştirdiğini ve apoptozu indükleyerek anti-kanser etkiler sergilediğini göstermektedir. Bu veriler, in vivo ve faz çalışmaları tamamlandıktan sonra flavopiridolün meme kanser tedavisi için etkili bir terapötik molekül olabileceğini ortaya koymaktadır.

Anahtar Sözcükler: Flavopiridol, meme kanseri, kanser kök hücresi, apoptoz, hücre siklusu, FTIR spektroskopisi

\section{Introduction}

Cancer consists of subpopulations of heterogeneous cells in terms of morphology, phenotype and function (1). Cancer stem cells (CSCs) are expressed as a small subpopulation within the heterogeneous population, which have the ability to create a high degree of tumor, self-renewal and differentiation (2). Studies on cancer treatment show that CSCs are resistant to standard therapies, including chemotherapy, radiotherapy and molecular targeting therapy (3). The main goal in new treatment methods is to target and eliminate CSCs.

Breast CSCs (BCSCs) were first shown in 2003 in a study in NOD/SCID (Nonobese diabetic/severe combined immunodeficiency) mice by $\mathrm{Al} \mathrm{Hajj} \mathrm{et} \mathrm{al.} \mathrm{(4).} \mathrm{In} \mathrm{the} \mathrm{study,} \mathrm{cells}$ with CD44 + CD24- phenotype in breast tissue have been shown to be more tumorogenic and exhibit similar characteristics with normal stem cells. CD44 adhesion molecule, one of the cell surface transmembrane glycoproteins, plays an important role in the proliferation, differentiation, motility and migration of CSCs (5). Compared to other cells in breast tumor tissue, the resistance of CSCs to standard therapies and features similar to stem cells highlights the need for new treatments targeting CSCs.

Among many new drugs developed for cancer-targeted treatments in recent years, cyclin-dependent kinase $(\mathrm{CDK})$ inhibitors have shown unique advantages in targeting various cancers (6). Flavopiridol, one of the best compounds studied, is the first CDK inhibitor evaluated in phase I/II clinical studies (7). Flavopiridol shows strong antitumor activity through many mechanisms, including cell cycle arrest, apoptosis induction and modulation of transcriptional regulation (7). Previous studies of our study team have shown that flavopiridol has cytotoxic and apoptotic effects on breast, lung and prostate CSCs (8-10). The aim of this study was to illuminate the cytotoxic effects of flavopiridol on CD44 +/CD24 BCSCs by molecular mechanisms.

\section{Methods}

\section{Production and Reproduction of MCF-7 Breast Cell Line}

The RPMI 1640 medium was used to reproduce and maintain the MCF-7 human breast cancer cell line. To the $500 \mathrm{~mL}$ sterile medium, $1 \%$ penicillin/streptomycin, fetal bovine serum inactivated by $10 \%$ heat, $1 \%$ amphotericin $\mathrm{B}$ and $1 \%$ L-glutamine were added. Cells planted in the medium were incubated at $37{ }^{\circ} \mathrm{C}, 5 \% \mathrm{CO}_{2}$ and humid environment. The cell line was monitored daily with an inverted microscope for viability, proliferation and infection. When more than $80 \%$ cell density was observed in flasks, cells were multiplied by passaging. Ethics committee approval was not required since our study was a cell culture study.

\section{Isolation of CD44 +/CD24- Breast Cancer Stem Cells}

Isolation of CD44 +/CD24- subpopulation in MCF-7 breast cancer cells was done using flow cytometry. Cells were kept in the dark for 15 minutes at $+4{ }^{\circ} \mathrm{C}$ by adding $10 \mu \mathrm{L}$ CD44-FITC and $10 \mu \mathrm{L}$ CD24-PE. At the end of the incubation period, the cell population with CD44 +/CD24-surface feature was sorted using the FACS Aria II (Beckton Dickinson) device. Cells were selected primarily from forward scatter and side scatter charts according to their size and granularity. The selection gate of the cells showing CD44 +/CD24-feature was created over the selected population. Cells were separated from the selected gate.

\section{Apoptotic Cell Measurement with Annexin-V Method}

Apoptotic cell analyzes were performed with Muse $^{\text {тм }}$ Cell Analyzer using Muse ${ }^{\mathrm{TM}}$ Annexin V \& Dead Cell. MCF-7 CSCs were planted in 6-well plates. The IC50 dose (500 nM) of flavopiridol obtained from our previous study (8) was added to the cells and they were incubated in a humid environment with $5 \% \mathrm{CO}_{2}$ for $72 \mathrm{~h}$ at $37{ }^{\circ} \mathrm{C}$. At the end of the incubation period, the cells were removed from the plate surface with trypsin and centrifuged at $1000 \mathrm{rpm}$ for 5 minutes. Muse ${ }^{\mathrm{TM}}$ Annexin V \& Dead Cell reagent was added to the cell pellet obtained and kept at room temperature for 20 minutes. Cells were analyzed at the end of the period.

\section{Cell Cycle Analysis}

Cell cycle analysis was done with the Muse ${ }^{\mathrm{TM}}$ Cell Analyzer using the Muse ${ }^{\mathrm{Tm}}$ Cell Cycle Kit. MCF-7 CSCs were planted in 6-well plates. The IC50 dose $(500 \mathrm{nM})$ of flavopiridol obtained from our previous study (8) was added to the cells and they were incubated for $72 \mathrm{~h}$ at $37{ }^{\circ} \mathrm{C}$ in $5 \% \mathrm{CO}_{2}$ and humid environment. At the end of the incubation period, the cells were removed from the plate surface with trypsin and centrifuged at 1000 rpm for 5 minutes. The cells were washed with cold 1x PBS by removing the supernatant. Cells were incubated in $70 \%$ ethanol for approximately three hours at $-20{ }^{\circ} \mathrm{C}$. After the time expired, 
Muse $^{\text {тM }}$ Cell Cycle reagent was added to the cells and they were kept in the dark for 30 minutes. Cells were then measured on the Muse $^{\text {TM }}$ Cell Analyzer instrument.

\section{Multicellular Tumor Spheroid Model}

Culture plates coated with agar were used to obtain tumor spheroids. RPMI-1640 medium without serum was added to the stock solution prepared as $3 \%$ agar. The agar-medium mixture prepared in a final concentration of $1 \%$ was poured into 6-well containers. After coating, the CD44+/CD24- cells were suspended in serum-free RPMI-1640 medium at a concentration of $1 \times 10^{4}$ cells/well and seeded to the wells.

\section{Preparation of Cell Samples for FTIR Analysis}

The CD44 +/CD24- cells isolated from the MCF-7 breast cancer cell line were seeded in a $25 \mathrm{~cm}^{2}$ flask. The cells outside the control group were incubated for $72 \mathrm{~h}$ by adding the IC50 dose $(500 \mathrm{nM})$ of flavopiridol. At the end of the incubation period, cells were washed. The cells obtained were re-suspended in isotonic solution $(0.9 \% \mathrm{NaCl})$ with a final cell concentration of approximately $1 \times 10^{6}$ cells $/ \mathrm{mL}$. In all sample groups, shots were taken with the same number of cells. Therefore, the number of cells placed in the attenuated total reflection (ATR) unit was expected to be the same.

\section{FTIR Spectroscopic Measurements}

FTIR analyzes were performed using the IRTracer-100 FTIR spectrometer (Shimadzu, Japan) combined with the ATR unit and equipped with a DLATGS detector. As stated and applied in recent literature (11-13), a few $\mu$ l of cell samples are sufficient for the shot and to form enough cell layer to cover the ATR crystal. In this study, $2 \mu \mathrm{l}$ of cell sample $\left(1 \times 10^{6}\right.$ cells $\left./ \mathrm{mL}\right)$ was placed in the crystal unit and left to stand for 12 minutes under dry air cleaning conditions at room temperature. Thus, the free water molecules in the cell sample were expected to evaporate. It was observed that the intensity in the range of 4000-3000 $\mathrm{cm}^{-1}$ caused by $\mathrm{O}-\mathrm{H}$ tension vibration was reduced in the spectra taken successively during the drying period, and then, when the dry cell sample was obtained, the intensity was balanced. It was measured by taking samples from each sample three times. A minimum of four spectra were recorded per sample in the range of $4000-800 \mathrm{~cm}^{-1}$. A total of 128 scanning averages of $4 \mathrm{~cm}^{-1}$ spectral resolution were obtained for each interferogram. In this study, air measurement was taken while the ATR unit as the background spectrum was empty. All cells were measured under the same conditions and parameters. Low concentration $\mathrm{NaCl}$ salts used as buffer solution did not affect the cell sample spectrum after drying.

\section{Processing of FTIR Data}

Spectral pretreatment, derivative spectrum of second degree, difference spectrum and Student t-tests were performed with 'Kinetics' (provided by Prof. Dr. Erik Goormaghtigh at Université Librede Bruxelles in Belgium) operating under MATLAB. FTIR cell sample shots (spectrum recording) were performed with the software software LabSolutions (Shimadzu, Japan). As is known, in the amide II region, a sharp IR peak originating from atmospheric water vapor is taken at $-1559 \mathrm{~cm}^{-1}$ (12). As in previous studies (12-16), the contributions from the water vapor in the atmosphere were removed in this study with reference to the IR peak between 1562 and $1555 \mathrm{~cm}^{-1}$. For this purpose, the water vapor spectrum in the atmosphere was introduced to the "Kinetics" program and the cells were extracted from the sample spectrum automatically. After baseline arrangement of the spectra, it was normalized in the Amid II region for an equal area between 1580 and $1485 \mathrm{~cm}^{-1}$. The absorbance spectra (at least 12 spectra recorded for each cell condition) with full pre-processing were averaged for all samples (baseline corrected and normalized). In order to calculate FTIR difference spectra, the average absorbance spectra of the control group and the flavopridol applied cell group were subtracted from each other. In order to make statistical comparisons between two different cell states, Student t-test was performed at each wavelength. The red dots here show standard deviations in wave numbers where significant differences occur (with $\alpha=0.1 \%$ significance). For different cell conditions, the B-method in OPUS 6.5 software (Bruker, Germany) was used to calculate band ratios in the mean absorbance spectra.

\section{Statistical Analysis}

Consecutive concentrations of flavopiridol were tested in three wells in experiments, and each experiment was repeated three times. SPSS Windows version 10.0 (SPSS Inc. Chicago, IL) was used for statistical evaluation of the data. Whether there was a significant difference in the results was examined using one-way ANOVA followed by Tukey's or Dunett's post-hoc test. A p value $<0.05$ was accepted as statistically significant.

\section{Results}

\section{Breast Cancer Stem Cells Isolation}

According to FACS-Aria flow cytometry results, the average percentages of MCF-7 CSCs and non-CSCs (bulk population) were $1.4 \%$ and $98.6 \%$, respectively (Figure 1 ).

\section{Effect of Flavopiridol on Cell Morphology}

It was noted that after applying flavopiridol, the number of BCSC decreased and some of the cells shrank, separated from
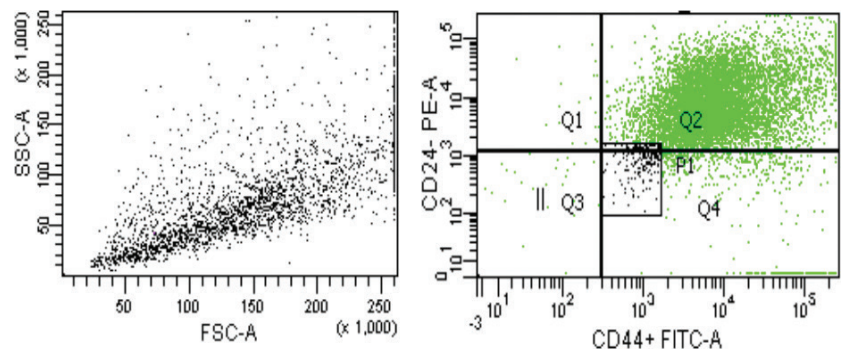

Figure 1. Breast cancer stem cell isolation. Flow cytometry showing the distribution of CD44 +/CD24 cells isolated from the MCF-7 breast cancer cell line. CD44 +/CD24 population is shown with "P1" 
the culture plate and rounded. In addition, it was observed that apoptotic bodies formed, some of the cells swelled and most of the cells lost their membrane integrity (Figure 2).

\section{Apoptotic Effect of Flavopiridol}

It was determined that flavopiridol had an apoptotic effect with the $\mathrm{IC}_{50}$ value $(500 \mathrm{nM})$ at the $72^{\text {nd }}$ hour determined according to the cytotoxic effect on BCSCs (Figure 3). When compared with the control group, a statistically significant difference in terms of early apoptotic cell ratios was determined $(\mathrm{p}<0.05)$.

\section{Effects of Flavopiridol on Cell Cycle}

After flavopiridol treatment, significant changes were found in cell cycle distribution. Compared with the control group,

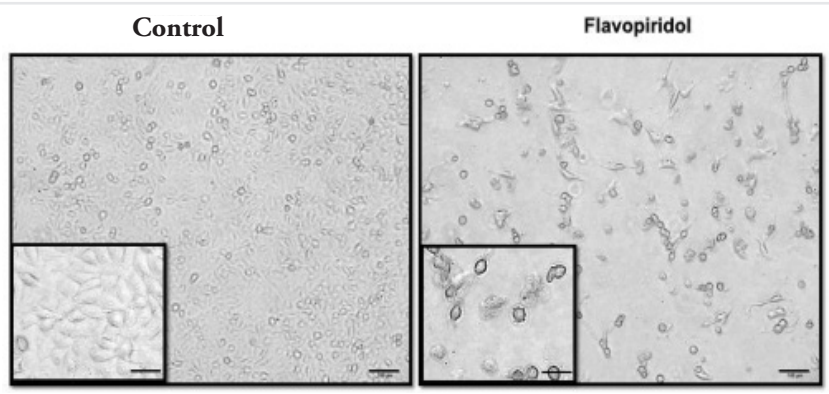

Figure 2. Morphological changes due to flavopiridol in MCF-7 cancer stem cells [Scale bar: $100 \mu \mathrm{m}$ (Outer); $50 \mu \mathrm{m}$ (Inner)]
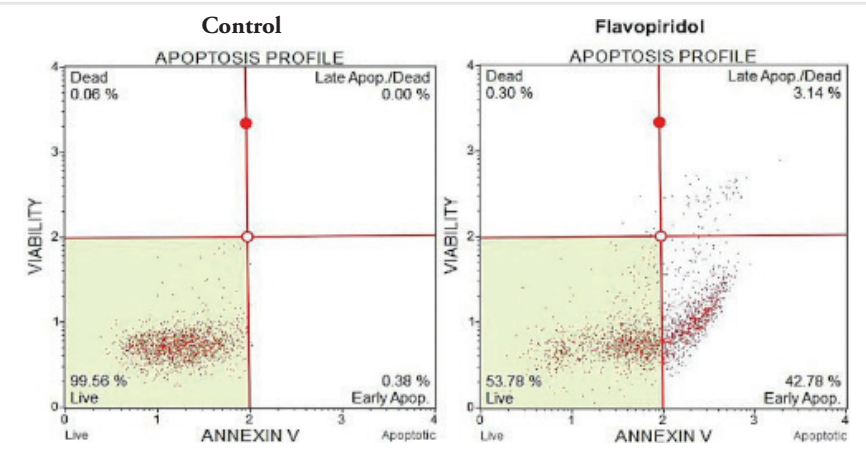

Figure 3. Live, dead, early apoptosis and late apoptosis values (\%) of flavopiridol in breast cancer stem cells
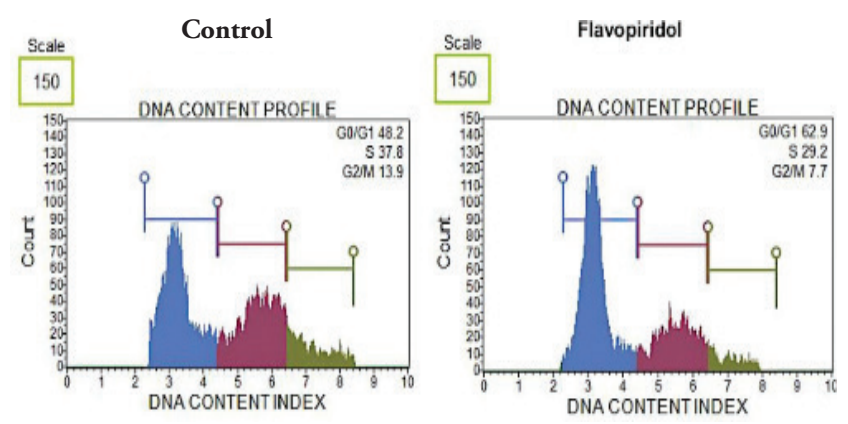

Figure 4. Effects of flavopiridol on cell cycle flavopiridol was found to specifically cause G0/G1 arrest (Figure 4).

\section{Effect of Flavopiridol on Spheroid Number and Diameter}

Multicellular tumor spheroid model studies used in the study of the effects of flavopiridol on the three-dimensional system showed that there was a statistically significant decrease in spheroid count $(\mathrm{p}<0.01)$ and spheroid diameter in the group given flavopiridol compared to the control group $(\mathrm{p}<0.05)$ (Figure 5).

\section{ATR-FTIR Results}

FTIR spectroscopy has been used very effectively in cell studies and biophysical research fields recently (11-17). In this study, the effect of flavopiridol molecule on biomolecules of MCF-7 CSCs was investigated using FTIR spectroscopy technique. As can be seen in the FTIR absorbance spectra of MCF-7 CSCs with control and flavopridol application (Figure 6), information about the biochemical components of the cell can be obtained quickly. Specific changes were seen in nucleic acids and carbohydrate regions (1250-900 $\mathrm{cm}^{-1}$ ) in MCF-7 CSCs where flavopridol was applied.

The FTIR-difference spectrum was calculated to more precisely reveal the spectral changes observed in the absorbance graph in Figure 6 (Figure 7). The FTIR-difference spectrum shows significant differences between 1250 and $900 \mathrm{~cm}^{-1}$. IR signals
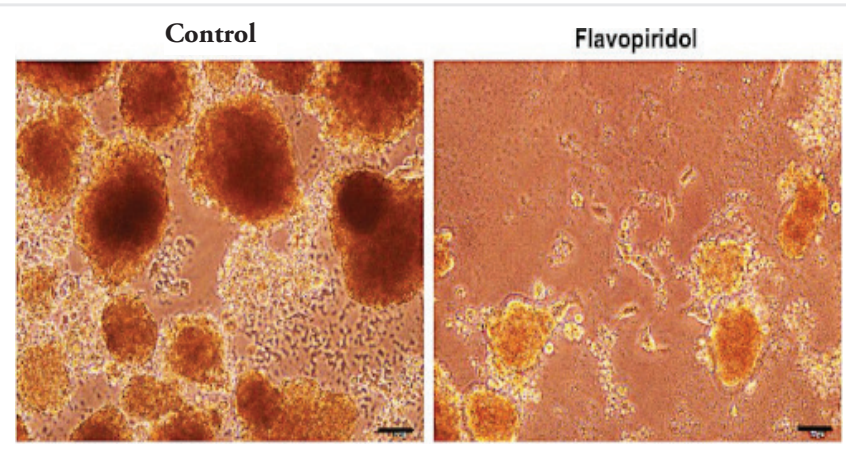

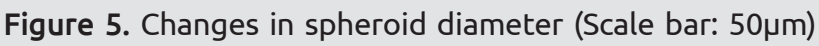
in breast cancer stem cells incubated with IC50 dose of flavopiridol

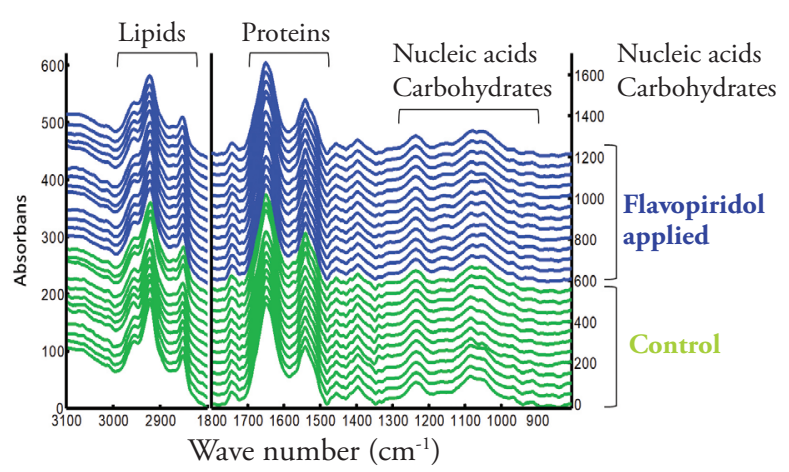

Figure 6. Fourier transform infrared absorbance spectra of MCF-7 cancer stem cells. Flavopiridol applied cell group is shown as "blue" and control cell group is "green" 
appear in this region of carbohydrates and phosphates, especially phosphate groups associated with nucleic acids (DNA, RNA) (16-19). In Figure 7, while significant changes were not observed for lipid and protein regions, IR signals in the region of 1250$1200 \mathrm{~cm}^{-1}$ and IR signal in $970 \mathrm{~cm}^{-1}$ decreased. This indicated that there was a decrease in the amount of DNA. On the other hand, an increase in absorbance was observed in IR peaks at 1157,1028 and $1005 \mathrm{~cm}^{-1}$. This emphasized the increase in the amount of glycogen in the cell. DNA/Amide II and glycogen/ Amide II ratios were calculated to reveal the effect of flavopiridol on changes in cell content (Table 1). The area in the range of 1280-1192 $\mathrm{cm}^{-1}$ (DNA) calculated on the average absorbance spectra for the DNA/Amide II ratio was divided into the area calculated in the range of $1580-1485 \mathrm{~cm}^{-1}$ (Amide II). The DNA/Amide II ratio was $0.28 \pm 0.006$ for the flavopiridol-treated cell group, and $0.30 \pm 0.003$ for the control group. In order to find the glycogen/Amide II ratio, the area between 1180-985 $\mathrm{cm}^{-1}$ (glycogen) was divided into the area of the Amide II region. The glycogen/Amide II ratio was $0.93 \pm 0.06$ for the flavopiridoltreated cell group and $0.78 \pm 0.06$ for the control group (Table 1 ). Therefore, there was a decrease in the DNA content of the cell group administered flavopiridol while there was an increase in the amount of glycogen.

In FTIR-second order spectrum, frequency shifts indicating structural changes in DNA were observed (Figure 8). The peaks originating from the DNA-related phosphate $(1237,1222,1085$, $\left.967 \mathrm{~cm}^{-1}\right)$ and glucose $\left(900-950 \mathrm{~cm}^{-1}\right)$ groups in the control cell group tended to shift to lower wave number (downshift: 1236, $1221,1083,965)\left(946,912 \mathrm{~cm}^{-1}\right)$, but a new peak appeared

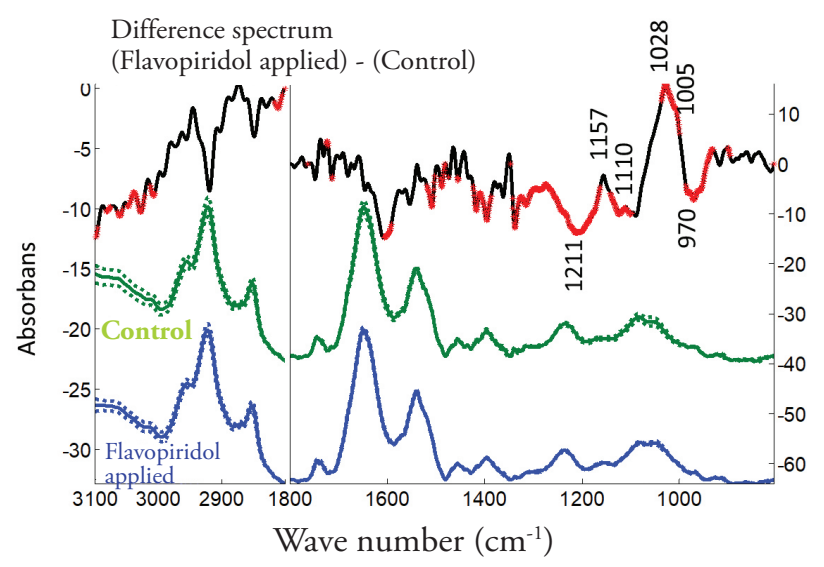

Figure 7. The Fourier transform infrared (FTIR) -difference spectrum and Student's t-test, expressed as "(Flavopiridol applied) - (control)" with MCF-7 cancer stem cells' flavopiridol applied cell group (blue) and control cell group (green) average absorbance spectra. The FTIRdifference spectrum was obtained by subtracting the mean absorbance spectrum of the control group cells from the mean absorbance spectrum of the Flavopiridol-treated cells. The Student t-test with a significance level of $a=0.1 \%$ at each wavelength was calculated. Thick dotted marks on the spectrum show statistically significant differences. The spectra are balanced for better readability at $1251 \mathrm{~cm}^{-1}$. These frequency changes clearly showed that the applied flavopiridol caused structural changes due to its binding and interaction with the cell DNA.

As a result, according to FTIR data, when the flavopiridol molecule is applied to MCF-7 CSCs, it causes changes in the cell's DNA. Thus, the mechanism of action of the flavopiridol molecule may be related to a decrease in the level of expression of nucleic acids and/or DNA damage.

\section{Discussion}

Breast cancer is among the leading causes of cancer-related deaths in women worldwide (20). While new treatment methods and advances in early diagnosis improve breast cancer mortality statistics, CSCs within the heterogeneous tumor mass are among the important causes of treatment failure with their features such as resistance to treatment, relapse and metastasis (2). For this reason, the development of new treatment strategies targeting the "CSCs", which are called the root of the tumor, gains great importance at this point. In this study, the effect of flavopiridol, which had highly cytotoxic properties on cancer cells, on BCSCs and the mechanisms underlying this effect were aimed to be elucidated. The obtained results showed that flavopiridol was effective on apoptosis, cell cycle and nucleic acid structure changes in the cell.

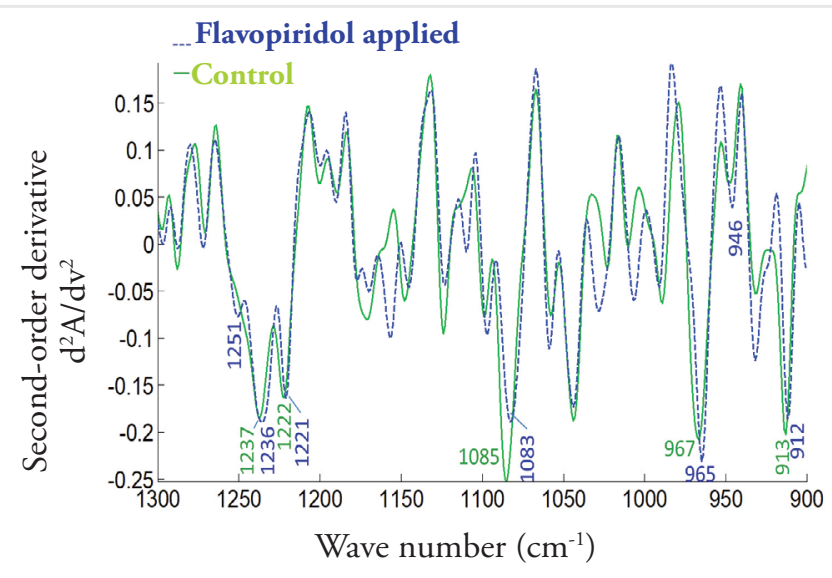

Figure 8. (a) The Fourier transform infrared second order derivative spectra (1300-900 cm-1 spectral range) of MCF-7 cancer stem cells flavopiridol-administered cell group (blue) and control cell group (green). Second order derivative spectra are obtained from the average absorbance spectra in Figure 7

Table 1. Calculated band area ratios for flavopiridol applied cell group and control group. The mean \pm standard error value was given for each cell group $(p<0.05)$

\begin{tabular}{|l|l|l|}
\hline Band ratio & Control cell group & $\begin{array}{l}\text { Flavopiridol applied } \\
\text { cell group }\end{array}$ \\
\hline DNA/Amide II & $0.30 \pm 0.003$ & $0.28 \pm 0.006$ \\
\hline Glycogen/Amide II & $0.78 \pm 0.06$ & $0.93 \pm 0.06$ \\
\hline
\end{tabular}


Specific cell surface markers are used for identification and isolation of BCSC. In this study, CD44+/CD24- cell phenotype was used to obtain BCSCs. Combinations of transmembrane proteins CD44 and CD24 are frequently used in isolation of BCSCs $(4,21,22)$. Al-Hajj et al. (4) reported in a study conducted in breast cancer that CD44 +/CD24-cells were more tumorogenic than $\mathrm{CD} 44+/ \mathrm{CD} 24+$ cells and this feature might be a marker of CSCs.

Flavopiridol, which is under investigation in different clinical and phase studies, exhibits antitumor activity with various mechanisms including apoptosis, cell cycle blockade, translation and inhibition of ribosome biogenesis. In a study on breast cancer cell lines (SKBR-3 and MB-468), it has been reported that flavopiridol causes G1 cell arrest and induces apoptosis (23). In a previous study, flavopiridol has been shown to have cytotoxic effects on BCSCs and cause inhibition of translation and ribosome biogenesis (8).

The results we obtained from this study showed that flavopiridol caused apoptotic effect in BCSCs. It has been shown in studies that the treatment of CSCs, which can survive with their antiapoptotic mechanisms, with flavopiridol causes apoptotic effect. In a study by Soner et al. (9) flavopiridol was shown to induce both early and late apoptosis in prostate CSCs. In addition, it was determined in that study that flavopiridol caused an increase in caspase- 3 , caspase- 8 and $\mathrm{p} 53$ expressions.

The discovery of CDKs, which were considered the main regulators of the cell cycle, paved the way for the design of potential inhibitors. Flavopiridol, a synthetic antitumor flavone derivative, was reported to significantly block cell cycle progression at the G1/S and G2/M points (24) by inhibition of some CDKs $(1,2,4,7)$. In this study, it was found that flavopiridol caused G0/G1 cell arrest in BCSCs. Shao et al. (25) reported that the ratio of MCF-7 cells in the G1 stage was $59 \%$ as a result of the application of $300 \mathrm{nM}$ flavopiridol, and this ratio was increased to $65 \%$ when $500 \mathrm{nM}$ flavopiridol was applied and it was stated that flavopiridol could block the cell cycle in the G1 stage.

There is an increasing interest in screening anti-tumor drugs in terms of their mechanism of action on cancer cells. However, revealing the mechanism of action of drugs at the cellular and molecular level provides important advantages in developing cancer treatment strategies. Recently, FTIR spectroscopy has been seen as a highly effective tool in defining the mechanism of action of drugs (11). In this study, the FTIR results we obtained with the difference spectrum, band frequency shifts and band field ratio calculations showed that flavopiridol had important effects on the nucleic acid structure and level. The downshift of the IR band originating from the phosphate group to low frequency shows that the phosphate group makes a strong H-bond (15). The band frequency shifts observed with the decrease in the amount of DNA in the flavopiridol-treated cell group and the new peak obtained reveal that the DNA has undergone structural and conformational changes as a result of the interaction of flavopiridol with DNA's phosphate groups.
The fact that flavopiridol caused changes in DNA structure in particular suggests that its lethal effect on cancer cells may be related to its interaction with DNA. In accordance with the results obtained, it has been shown that flavopiridol interacts with the DNA structure and that nucleic acids are among the possible targets of flavopiridol $(26,27)$. In a study conducted by Bible et al. (26) in A549 human lung cancer cell line, it was revealed that flavopiridol had effects on DNA and RNA structure and synthesis. Researchers have been shown that RNA synthesis is inhibited at $500 \mathrm{nM}$ flavopiridol concentrations and that it binds to DNA similar to binding to ethidium bromide and Hoechst 33258 (26). Similarly, Ray and his team used various spectroscopic and calorimetric techniques to describe the direct effect of flavopiridol on the structural and conformational changes and thermodynamic orientation of DNA (27). The team's ATR-FTIR results showed that flavopiridol interacted with the corrugated structure of DNA (27). Collectively, all of these results emphasize that nucleic acids may be the target of flavopiridol.

\section{Study Limitations}

Our study shows that flavopiridol is effective in breast CSCs in vitro. However, the effects of flavopiridol on breast cancer should be supported by in vivo studies.

\section{Conclusion}

The findings revealed that flavopiridol caused cell cycle arrest and effectively induced apoptosis. Results from the multicellular spheroid model showed that flavopiridol significantly suppressed the formation of spheroids specific for CSCs. Our FTIR findings, obtained with the difference spectrum, band area ratio and frequency shift calculations, revealed a potential view that flavopiridol interacted with the nucleic acid construct and that DNA might be the secondary target of flavopiridol. These findings obtained as a result of in vitro studies showed that flavopiridol might have a potential therapeutic value against breast CSCs. However, there is a need to support the effective roles of flavopiridol in targeting breast CSCs with in vivo and clinical studies.

\section{Ethics}

Ethics Committee Approval: Ethics committee approval was not required since our study was a cell culture study.

Peer-review: Externally peer reviewed.

\section{Authorship Contributions}

Concept: E.A., G.Ö., Design: E.A., Data Collection or Processing: E.A., G.G., Analysis or Interpretation: E.A., G.G., G.Ö., Literature Search: E.A., G.G., Writing: E.A., G.G.

Conflict of Interest: No conflict of interest was declared by the authors.

Financial Disclosure: The authors declared that this study received no financial support. 


\section{References}

1. Liu S, Wicha MS. Targeting breast cancer stem cells. J Clin Oncol 2010;28:4006-12.

2. Reya T, Morrison SJ, Clarke MF, Weissman IL. Stem cells. Cancer, and cancer stem cells. Nature 2001;414:105-11.

3. Frank NY, Schatton T, Frank MH. The therapeutic promise of the cancer stem cell concept. J Clin Invest 2010;120:41-50.

4. Al Hajj M, Wicha MS, Benito Hernandez A, Morrison SJ, Clarke MF. Prospective identification of tumorigenic breast cancer cells. Proc Natl Acad Sci U S A 2003;100:3983-8.

5. Thapa R, Wilson GD. The Importance of CD44 as a Stem Cell Biomarker and Therapeutic Target in Cancer. Stem Cells Int 2016;2016:2087204.

6. DiPippo AJ, Patel NK, Barnett CM. Cyclin-Dependent Kinase Inhibitors for the Treatment of Breast Cancer: Past, Present, and Future. Pharmacotherapy 2016;36:652-67.

7. Shapiro GI. Preclinical and clinical development of the cyclindependent kinase inhibitor flavopiridol. Clin Cancer Res 2004; 10:4270-5.

8. Erol A, Acikgoz E, Guven U, Duzagac F, Turkkani A, Colcimen N, et al. Ribosome biogenesis mediates antitumor activity of flavopiridol in CD44+/CD24- breast cancer stem cells. Oncol Lett 2017;14:643340.

9. Soner BC, Aktug H, Acikgoz E, Duzagac F, Güven U, Ayla S, et al. Induced growth inhibition, cell cycle arrest and apoptosis in CD133+/CD44+ prostate cancer stem cells by flavopiridol. Int J Mol Med 2014;34:1249-56.

10. Bozok Cetintas V, Acikgoz E, Yigitturk G, Demir K, Oktem G, Tezcanlı Kaymaz B, et al. Effects of flavopiridol on critical regulation pathways of CD133high/CD44high lung cancer stem cells. Medicine (Baltimore) 2016;95:5150.

11. Derenne A, Verdonck M, Goormaghtigh E. The Effect of Anticancer Drugs on Seven Cell Lines Monitored by FTIR Spectroscopy. Analyst 2012;137:3255-64.

12. Goormaghtigh E, Ruysschaert JM. Subtraction of Atmospheric Water Contribution in Fourier Transform Infrared Spectroscopy of Biological Membranes and Proteins. Spectrochimica Acta Part A: Molecular Spectroscopy 1994;50:2137-44.

13. Güler G, Acikgoz E, Karabay Yavasoglu NÜ, Bakan B, Goormaghtigh E, Aktug H. Deciphering the Biochemical Similarities and Differences among Mouse Embryonic Stem Cells, Somatic and Cancer Cells Using ATR-FTIR Spectroscopy. Analyst 2018;143:1624-34.

14. Güler G, Acikgoz E, Öktem G. Determination of Cellular Differences of CD133+/CD44+ Prostate Cancer Stem Cells in Two-Dimensional and Three-Dimensional Media by Fourier Transformation Infrared Spectroscopy. Dokuz Eylül Üniversitesi Tıp Fakültesi Dergisi 2019;33:45-56.
15. Güler G, Gärtner RM, Ziegler C, Mäntele W. Lipid-Protein Interactions in the Regulated Betaine Symporter BetP Probed by Infrared Spectroscopy. J Biol Chem 2016;291:4295-307.

16. Güler G, Guven U, Oktem G. Characterization of CD133 + /CD44 + Human Prostate Cancer Stem Cells with ATR-FTIR Spectroscopy. Analyst 2019;144:2138-49.

17. Acikgoz E, Güler G, Camlar M, Oktem G, Aktug H. Glycogen Synthase Kinase-3 Inhibition in Glioblastoma Multiforme Cells Induces Apoptosis, Cell Cycle Arrest and Changing Biomolecular Structure. Spectrochim Acta A Mol Biomol Spectrosc 2019;209:15064.

18. Diem M, Boydston-White S, Chiriboga L. Infrared Spectroscopy of Cells and Tissues: Shining Light onto a Novel Subject. Appl Spectrosc 1999;53:148-61.

19. Ozdil B, Güler G, Acikgoz E, Kocaturk DC, Aktug H. The Effect of Extracellular Matrix on the Differentiation of Mouse Embryonic Stem Cells. J Cell Biochem 2019;121:269-83.

20. Siegel RL, Miller KD, Jemal A. Cancer statistics, 2016. CA Cancer J Clin 2016;66:7-30.

21. Sheridan C, Kishimoto H, Fuchs RK, Mehrotra S, Bhat-Nakshatri P, Turner $\mathrm{CH}$, et al. CD44+/CD24- breast cancer cells exhibit enhanced invasive properties: an early step necessary for metastasis. Breast Cancer Res 2006;8:59.

22. Abraham BK, Fritz P, McClellan M, Hauptvogel P, Athelogou M, Brauch H. Prevalence of CD44+/CD24-/low cells in breast cancer may not be associated with clinical outcome but may favor distant metastasis. Clin Cancer Res 2005;11:1154-9.

23. Wittmann S, Bali P, Donapaty S, Nimmanapalli R, Guo F, Yamaguchi $\mathrm{H}$, et al. Flavopiridol down-regulates antiapoptotic proteins and sensitizes human breast cancer cells to epothilone B-induced apoptosis. Cancer Res 2003;63:93-9.

24. Senderowicz AM. Flavopiridol: the first cyclin-dependent kinase inhibitor in human clinical trials. Invest New Drugs 1999;17:31320.

25. Shao X, Gao D, Wang Y, Jin F, Wu Q, Liu H. Application of metabolomics to investigate the antitumor mechanism of flavopiridol in MCF-7 breast cancer cells. J Chromatogr B Analyt Technol Biomed Life Sci 2016;1025:40-7.

26. Bible KC, Bible RH Jr, Kottke TJ, Svingen PA, Xu K, Pang YP, et al. Flavopiridol binds to duplex DNA. Cancer Res 2000;60:2419-28.

27. Ray B, Agarwal S, Lohani N, Rajeswari MR, Mehrotra R. Structural, conformational and thermodynamic aspects of groove-directedintercalation of flavopiridol into DNA. J Biomol Struct Dyn 2016;34:2518-35. 